\title{
HOW TO USE ACTION RESEACH IN TEACHER TRAINING PROGRAMMES
}

\begin{abstract}
This article focuses on action research study which was conducted with the third class students of English Language Teaching Department, which was completed in four weeks.The aim was to introduce action research to teachers-in-preparation and encourage them to use it after their graduation to help them to become reflective teachers..Before this action research began,teachers-in-preparation had been tutoring for five weeks.In the first week of the action research study,in the classroom, students tried to find common teaching problems they had while tutoring and they used data collection techniques such as video-taping and peer observation, and in the second week they shared what they had learned about their problems and what their action plans were.In later weeks they shared the results of their the action plans and how successful their plans were.It was hoped that teachers-in-preparation would become more flexible in their thinking, be more open to new ideas and would learn to develop professional autonomy.
\end{abstract}

\section{Key Words}

Action research ,reflection,self-assessment 


\section{Introduction}

Action research has grown popularity in recent years and it is becoming an essential part of teacher training, and it is in the center of professional lives of teachers as it enables teachers and teachers-in- preparation to reflect on their teaching, and allows teachers who want to examine events in their own classrooms to take constructive steps towards solving immediate problems. What is action research? Kemmis and Mc Taggart define action research as "trying out ideas in practice as a means of improvement and as a means of increasing knowledge about the curriculum ,teaching and learning."(1982:5 as cited in Thorne and Qiang,1996:255). According to Michael Wallace action research is " the systematic collection and analysis of data relating to the improvement of some aspects of professional practice."(1998:1). Action research nearly always stems from specific problems or issues arising out of teachers' professional practice. It is problem-focused and very practical in its intended outcomes. It is based on the following assumptions:

- Teachers work best on problems they have identified for themselves.

- Teachers become more effective when encouraged to examine and assess their own work and then consider ways of working differently.

- Teachers help each other by working collaboratively.

- Working with colleagues helps teachers in their professional development(Watts,1985:118 as cited in Ferrance,2000:1).

There are different types of action research:

1. Individual teacher research: It centers around a single issue in the classroom. The teacher wants to find solutions to different kinds of problems such as problems of classroom management, student learning, the use of materials, teaching and learning strategies,etc.It is conducted by individual teachers in response to their own particular problems in their classrooms.

2. Collaborative action research: It includes two or more teachers and the issue may involve one classroom or a common problem shared by a lot of classrooms. Through sharing their ideas with colleagues teachers develop stronger relationship.

3. School-wide research: It focuses on issues common to whole school and the staff work together. As it becomes a part of the school culture, there will be increased collaboration among departments.

Action research is an approach to collecting and interpreting data that involves a clear, repeated cycle of procedures (Bailey,2001:490).These repeated steps are:

1. An issue or a problem is identified.

2. Relevant data are gathered.

3. A plan of action is designed to bring about a change in the classroom behaviour.

4. The plan of action is implemented.

5. The action is observed.

6. Results are monitored and observation is reflected on.

7. 7-If the problem has been solved, researchers may begin to work on another one; if not, the original problem is redefined and the cycle is repeated.

Action research aims at bringing about changes for the better in the specific situation being investigated. It is characterized as being a participatory, self-reflective, collaborative and contextbased approach to research(Nunan,1994:63), and "action 
research demands a high level of professional commitment from teachers"(Thorne and Qiang,1996:255). The idea of action research can be found in Kurt Lewin, a social psychologist and educator whose work on action research began in 1940s as a way of investigating social problems in the USA. Stephen Corey, a professor at Teachers College at Columbia University was among the first to use action research in the field of education:

"We are convinced that the disposition to study...the consequences of our own teaching is more likely to change and improve our practices than is reading about what someone else has discovered of his teaching."(Corey,1953:70 as cited in Ferrance,2000:7).

However, in 1950s it was attacked as unscientific and the work of amateurs(McFarland and Stansell,1993:15 as cited in Ferrance,2000:8).In the 1970s action research emerged again and began to hold great value. Since 1980s there has been a dramatic rise in its popularity, and nowadays it is seen as a vehicle for professional development with a greater focus on the teacher than before(Noffke and Stevenson,1995 as cited in Ferrance, 2000:8).

"Action research emphasizes the involvement of teachers in problems in their own classrooms and has as its primary goal the in-service training and development of the teacher rather than the acquisition of general knowledge in the field of education."(Borg,1965:313 as cited in Ferrance,2000:8).

For the success of action research students are of crucial importance because they need to know that they can contribute to the quality of their education by showing willingness to be video-taped or interviewed.Students are a wonderful source of feedback because their information is based on a whole series of lessons and they generally have a quite clear idea of how well they are learning and why.Furthermore,they usually try hard to give helpful feedback and this process enhances teacherstudent relationship.

Recently a lot of action research studies have been carried out by language teachers to investigate issues in their classrooms. For example, Kebir(1994,as cited in Bailey,2001:495) studied adult language learners'communication strategies . Another one is by Helen Sitler, who tried to evoke students' verbal response to instructions. Sitler informed that no method course had ever presented her with such a stimulating possibility.She said that she has learned the value of becoming aware of her teaching behaviours and of investigating their consequences for students' learning. The action research study by Zübeyde Tezel is about getting students to talk during tutorials. Tezel reported that by doing action research she felt she addressed her students'needs much better because it helped to close the gap between the predetermined methods and her own class. She was able to choose what would work for her students rather than applying the most recent and popular methods.

Rebecca Wisniewski from Charlotte M. Murkland School in Lowell, Massachusetts wrote about her experience with action research.They worked collaboratively as a whole school and their question was "what can we provide for effective reading instruction for third and fourth grade English language learners who are limited readers or nonreaders?" As a team they interviewed their students and asked their views about which of their strategies helped them become stronger readers.She found that action research helped her to put some of her assumptions to the test.She said that she made unexpected discoveries about her own teaching by listening carefully to students.

In Thorne and Qiang's project they introduced the notion of action research into China to encourage reflective teaching and 
classroom research among trainee teachers.Trainee teachers acted as real classroom teachers, and the project was divided into two stages: during the first semester the participants were familiarized with the action research approach and studied ways to collect and analyze data through learner diaries, observation sheet and questionnaires. During the second semester trainee teachers carried out their own action research with their classes. Doing action research gave trainee teachers a strong desire to change.With constant reflection and modification of their techniques they succeeded in motivating their students.

Another example is an action research study about learner strategy training conducted by David Nunan.He decided to see whether incorporating a learner strategy and self-monitoring dimension into the classroom would help students develop the self-reflective orientation they would need to realize their potential as university students.Students reported on their strategy use and personal goals for strategy development.By the end of the 12-week period, students who took part in the action research project were more likely to exploit opportunities that existed for language learning and they also seemed to make greater connections between English and content courses.

These examples show that action research is based on problems that are real for teachers and relevant to students.

Generally teachers are taught different methods at university but they are seldom taught to observe the effects of these methods. These methods have been imposed on trainee teachers and teachers assuming that they would bring the best results in every teaching context and with any group of students.They do not take into consideration the unique nature of each class so they may not work well in each class.Action research could give both trainee teachers and teachers a means of doing it. Farrell argued that language teacher education programs emphasized "how to teach" with its main stress on methods rather than what it means to be a language teacher (2006:218).

This study aims to introduce action research to teachersin-preparation(how to collect data and how to analyse and evaluate data) and help them understand that through action research teachers can learn about themselves, their students and their teaching styles, and can find ways to improve themselves continuously .Action research could help them identify and examine their own ideas and attitudes about language and learning and identify areas for further research in their own classroom as trainee teachers should develop skills of evaluating,planning and monitoring their own professional activities.It is hoped that it would encourage them to use action research after their graduation in their real classrooms to learn more about and reflect on their teaching and solve their problems by using it.

\section{Materials ans methods}

$173^{\text {rd }}$ class students of English Language Teaching Department in Buca Faculty of Education at Dokuz Eylül University used action research study with the students they had been tutoring for five weeks. In the first week of the action research study students tried to identify common problems they had while tutoring. They identified their problems by using the results of CATs(classroom assessment techniques)they applied before and the diaries they kept after each lesson. The problems they posed are gathered under three headings:

$1^{\text {st }}$ group's problem: "How can I use more English during the lessons and make my students understand it?" 
$2^{\text {nd }}$ group's problem:How can I increase the amount of my students'speaking time in English in the classroom?"

$3^{\text {rd }}$ group's problem: "How can I motivate my students?"

They also discussed about ways of data collection and used video and audio taping, peer observation, teacher-student interviews and questionnaires as data collection techniques.In the second week they shared what they had learned about their problems and what their action plans were.After this lesson they implemented their plans of action for two weeks, video or audio taped their lessons or used peer observation and then they viewed the tape or read their peer teacher's notes to find out whether their action plans were effective or not.In the third and fourth weeks they shared the results of their implementing the action plans and how successful their plans were.

\section{Results}

The details of the results of 3 teachers-in-preparation's action research study(they were in the 2nd group), which is about increasing the amount of their students' speaking time in English during their lessons will be examined as it would not be possible to report about all teachers-in-preparation's action research studies. The followings are the details of their study:

\section{A-Posing A Problem:}

During their lessons all three realized that their students were not communicating with them in English and they generally preferred Turkish even though teachers-in-preparation gave verbal instructions in English and their students were able to understand their teachers' English sentences. Therefore, they accepted it as a real problem and raised this question:
"What can I do to increase my student's speaking time in English during the lesson?"

\section{B-Seeking Knowledge:}

Having identified a problem, they needed to discover more about their problem. All three used video-taping and beside video-taping one of them used teacher-student interview which included such questions:

"Was the lesson interesting? If not, how do you want to learn it?"

The student's answer: "Not so interesting. If technology and computer are included in the lesson, it may be more interesting."

Another one used a short questionnaire which includes some sentences such as :

a-I like speaking English.

b-I feel relaxed while speaking English.

c-I think speaking English is difficult.

and the student answered them by using "I agree, I don't agree, etc." When his answers were examined, it was understood that he wants to speak English but he doesn't feel relaxed while speaking English.

The video-tape was revealing also. During the lesson of one of the three teachers-in-preparation the student's talking time in English was 5 minutes and he used Turkish while he was doing the activities, and the teacher spoke for 20 minutes during the lesson. This teacher-in-preparation also realized that she used very long and complicated sentences for her student's level. Other teacher-in-preparation's student talked for 10 minutes during her lesson. The 3rd teacher-in-preparation's student 
used Turkish as he was worried about making mistakes. The video-taping also revealed that she corrected every mistake of her student, which made him confused and anxious.

\section{C-Planning An Action:}

Based on the information they got, they decided to take some steps:

$1^{\text {st }}$ teacher-in-preparation's steps:

a-Using simpler and shorter sentences in the lesson

b-Using computer in the lesson

c-Using the following speaking activities:

1-Telling stories:In this activitiy the teacher shows some pictures to the student and ask such questions:

- Who are the people in the picture?

- What is happening now?

- What happened before?

- What is going to happen later?

2-Talking about a story book: The student chooses and reads it before the lesson and the teacher asks some questions and they discuss it.

3- What will happen?:The teacher chooses some interesting videos, but doesn't play all the video,pauses at some points and asks the student to guess what will happen.

4-Guessing Game:The teacher keeps an object in the room in his/her mind and the student tries to find it by asking yes/no questions.

$2^{\text {nd }}$ teacher-in-preparation's steps:

a-Activating background information related to their subject.
b-Information-gap activity:The teacher and the student have the same picture but with some differences.Without looking at the teacher's picture the student tries to find them by asking questions.

c-Famous People:The student thinks of a famous person and interviews with the teacher as if he/she were that famous person.

$3^{\text {rd }}$ teacher-in-preparation's steps:

a-Using videos, powerpoint slides:Watching a video and asking questions about it,both the teacher and the student asked questions. Watching slides and saying whether they like or hate the activities in the slides and why.

b-Using colorful pictures related to their topic and talking about them.

c-Songs: Listening to a song and filling in the blanks and asking questions about the topic of the song, what the title could be,etc.

d-She decided to correct her student's mistakes less.

\section{D-Implementing and Observing the Action:}

They applied their activities and two of them video-taped, and one audio-recorded their lessons.

The following table shows the results of the activities of the $1^{\text {st }}$ teacher-in-preparation. 


\begin{tabular}{|l|c|c|c|c|}
\hline & $\begin{array}{c}\text { Total } \\
\text { Time }\end{array}$ & $\begin{array}{c}\text { Student's } \\
\text { Speaking } \\
\text { Time }\end{array}$ & $\begin{array}{c}\text { Teacher's } \\
\text { Speaking } \\
\text { Time }\end{array}$ & Computer \\
\hline Telling Stories & 20 & 14 & 6 & $\boldsymbol{X}$ \\
\hline $\begin{array}{l}\text { Talking About a } \\
\text { Story }\end{array}$ & 13 & 9 & 4 & $\boldsymbol{X}$ \\
\hline $\begin{array}{l}\text { What Will } \\
\text { Happen? }\end{array}$ & 20 & 13 & 7 & X \\
\hline Guessing Game & 15 & 10 & 5 & \\
\hline
\end{tabular}

She stated that when the table is examined, it is clear that the activities are useful for the student.He did not speak non-stop during the activities but in two weeks it is really a great success for the student to spend so much time speaking in English. During the lesson she tried to minimize her talking time .It was really difficult for her as her student usually wanted help while he was asking questions.She helped him by giving short and clear examples and she didn't speak more than he did. At the end of the lesson she asked her student some questions to get feedback:

Q1-Did you feel relaxed during your talking time?

A:Mostly I was relaxed but when I couldn't find the word to express my thoughts, I was nervous.

Q2-Were the last two weeks useful for your speaking skills in English?

A:Yes , I talked more than the former weeks and I think these activities were for useful for me .

Q3-Which type of lesson do you prefer ,speaking activity dominant lesson or workbook activity dominant one ?

A:Both of them should be included in the lesson. $2^{\text {nd }}$ teacher-in-preparation audio -recorded her lesson and analyzed the tape in terms of the amount of the time the student spent talking. During the first activity(activating background knowledge)her student spent a total of 5 minutes talking.The student spent a total of 10 minutes talking during activity 2 (Information-gap) and lastly the student spent 10 minutes talking during activity 3 (famous people).

She also found out her student's ideas about the lesson after the lesson was over by asking questions such as:

Q-Did the lesson cover your needs?

A-Sometimes yes,sometimes no, but I think I have improved my speaking by being involved in these activities.

Q-Did you like the activities?Were they useful?

A- Yes, I did,especially information-gap activity.They were useful to improve speaking.

The $3^{\text {rd }}$ teacher-in-preparation video-recorded her lesson and viewed it later and noticed how her student tried to respond her questions in English. She used simple sentences while asking questions and she gave examples and background information about the topic and showed pictures so the student didn't use his native language.While watching videos and powerpoint slides her student spoke in English only four minutes.In the second lesson she used a song which he particularly liked as he was keen on talking about songs. She also realized that the amount of her correction decreased.The student's speaking time was 12 minutes, which was an important improvement when it was thought that the student had never used English with the fear of making mistakes.

After the lesson she interviewed with her student to find out his ideas about the lesson.The followings are her interview questions: 
1. How did you find the lesson?

2. What did you enjoy most about the lesson?

3. Did you have any difficulty in the lesson?

The student said that the lesson was enjoyable and he enjoyed himself most while listening to the song, but he had difficulty while he was filling in the gaps in the song.

\section{Discussion}

\section{E-Reflecting}

All three teachers-in-preparation think that speaking skill has an important role in language teaching and learning. Learning English does not just mean listening to the teacher and taking notes .Learners have to be taught to speak as well as to listen. Therefore, they should be active participants, not passive listeners.Their students had limited language knowledge but the activities they carefully chose enabled their students to speak more.

They agreed that this action research study showed them that if a teacher wants to improve his/her students'skills in English, there is no obstacle to achieve his/her goal. They also believed that they improved their teaching skills as well as learning how to choose activities according to their students' needs. They have become more confident about their teaching, more aware of their teaching problems and how they could solve them. They began to ask questions such as "What do I know now that I did not know before? Am I closer to solving the problem? Is there a bigger problem that needs to be resolved?" One of them stated that before this action research study began, she had thought that it would not be useful for her student and would not reach success at all, but after the project was completed, she said she could see the improvement. It was not so great but it was enough when the limited time was considered.

\section{Conclusion}

\section{What They Have Learned About the Action Research}

They stated that by doing action research they analyzed their students' needs and used methods and activities which were suitable for their students' needs. With the help of action research study their problems diminished. They informed that they would go on using action research after graduation to investigate how they can do their best to teach and help their students. Through action research teachers-in-preparation will have an opportunity to develop their professional autonomy and use classroom activities which they may not attempt to use otherwise.

Many teachers like action research because the emphasis is on problem solving and teachers can see the relevance of doing it (Gebhard,2003:76).Teachers can address real problems in their classes and can make teaching and learning process more effective. Van Lier (1993,as cited in Gebhard,2003:70) says action research "is a way of working in which every answer raises new questions, and one can thus never quite say ' $\mathrm{I}$ 've finished". By conducting an action research study teachers "gain awareness of their teaching beliefs and practices and learn "to see teaching differently."(Gebhard and Oprandy,2003:4) .According to Aydan Ersöz self-inquiry and self-discovery are really important and effective in changing our behaviours and beliefs. Action research as a way of critical reflection enables us to take more responsibility for our actions and to develop professional flexibility(2012:42). Educators involved in action 
research become more flexible in their thinking and more open to new ideas (Pine,1981 as cited in Ferrance,2000:15).The results of action research study are valuable not only for teachers' own learning and development but also they can contribute to the advancement of professional knowledge as a whole (Ur,1996:329). At university the curriculum should prepare trainee teachers as autonomous, analytical and critical teachers capable of carrying out classroom teaching and research, and of managing their own professional development.It could not be claimed that action research is the answer to all questions and problems of teacher education but it is plausible to think that a structured training programme for basic classroom research is a useful and motivating addition to teacher education programmes (Thorne and Quiang,1995:261).

In conclusion, some reasons could be listed why teachers should do action research (Sitler and Tezel 2003):

a- Teaching can be accomplished if teachers follow students, not the packaged methods, to structure the learning/ teaching process.

b- Action research can narrow the gap between researchers and teachers (Lieberman 1986; Nunan 1995).

c- Through the use of action research, teachers can find their own way among all those methods and theories and texts.

d- The real issues and problems can be addressed (Nunan 1990).

e- Action research is a part of professional development. It provides a means for teachers to become more aware and reflective in their teaching.

\section{References}

Bailey, M. Katleen (2001) "Action Research, Teacher Research and Classroom Research in Language Teaching" in CelceMurcia Marianne (ed.) Teaching English as a Second or Foreign Language, USA: Heinle and Heinle Thomson Learning.

Ersöz, Aydan (2012) "Reflections on a Seminar at İzmir University of Economics, 8 September, 2011", News On-Line (Together We Stand) The INGED Newsletter, Issue. 1 March, p: 42.

Farrell, T. S. C. (2006)The First Year of Language Teaching: Imposing Order, System, 34.

Ferrance, Eileen (2000) Action Research (online), Available: www.lab.brown.edu/pubs/.../act_research p...

Gebhard, Jerry G. (2003) "Problem Posing and Solving with Action Research" in Gebhard Jerry, Oprandy Robert and Richards Jack C. Language Teaching Awareness, Edinburgh: Cambridge University Press.

Murphy, John M. (2001) "Reflective Teaching in ELT" in CelceMurcia Marianne (ed.) Teaching English as a Second Language, USA: Heinle and Heinle Thomson Learning.

Nunan, David (1994) "Action research in the Language Classroom"in Richards Jack C. and Nunan David (eds.) Second Language Teacher Education, Cambridge: Cambridge University Press.

Nunan, David (2002) "Learner Strategy Training in the Classroom:An Action Research Study" in Richards Jack and Renandya A.Willy (eds) Methodology in Language Teaching, Cambridge: Cambridge University Press. 
Sitler, Helen Collins and Tezel, Zübeyde (2003) "Two Action Research Projects" in Gebhard Jerry G., Oprandy Robert and Richards Jack C. Language Teaching Awareness, Edinburgh: Cambridge University Press.

Thorne, Christine and Qiang, Wang (1996) "Action Research in Language Teacher Education", ELT Journal, vol. 50, no. 3 July, pp. 254-261.

Ur,Penny (1996) A Course in Language Teaching: Practice and Theory,Cambridge: Cambridge University Press.

Wallace J. Michael (1998). Action Research For Language Teachers, Cambridge: Cambridge University Press. 